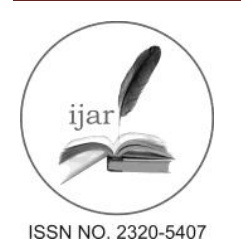

Journal homepage: http://www.journalijar.com

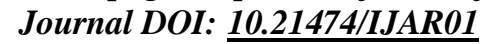

INTERNATIONAL JOURNAL

OF ADVANCED RESEARCH

RESEARCH ARTICLE

\title{
ACHYRANTHES ASPERA L.: MULTIPLE THERAPEUTIC USES AMONG VARIOUS TRIBES OF KUMAUN, UTTARAKHAND.
}

Deepika Bhatt, G.C. Joshi, Depshikha Arya, J.C. Arya, G.V.R Joseph, K.K.Ratha.

\section{Manuscript Info}

Manuscript History:

Received: 14 April 2016

Final Accepted: 19 May 2016

Published Online: June 2016

Key words:

Tribes, Achyranthes aspera L., Allergic dermatitis, Jaundice, Raji/

Vanrawat

*Corresponding Author

Deepika Bhatt.

\begin{abstract}
Achyranthes aspera L. (Amaranthaceae) has long been used in different systems of medicine in the treatment of various ailments, found as a weed throughout India. Though almost all of its parts are used in traditional systems of medicines, leaves, roots and shoots are the most important parts which are used medicinally. The review reveals that wide numbers of phytochemical constituents have been isolated from the plant which possesses activities like antiperiodic, diuretic, purgative, laxative, antiasthmatic, hepatoprotective, anti-allergic and various other important medicinal properties. The present article gives an account of various local health traditions along with their formulation and validation, related with this plant species among the tribals of the Kumaun region.
\end{abstract}

Copy.Right, IJAR, 2016, All rights reserved.

\section{Introduction:-}

Nature is a resource of therapeutic (Medicinal) agents for hundreds of years and a remarkable number of recent or novel drugs have been isolated from natural sources [Cragg et al., 2001]. Knowledge of herbs has been handed down from generation to generation for thousands of years. Herbal drugs constitute a major part in all traditional systems of medicines. Herbal medicine is a triumph of popular therapeutic diversity. Plants above all other agents have been used for medicine from time immemorial because they have fitted the immediate personal need, are easily accessible and inexpensive [Mukherjee, 2008].

In the recent past there has been an incredible increase in the use of plants based health products in developing as well as developed countries ensuring in an exponential development of herbal products worldwide. The therapeutic properties of medicinal plants are mainly due to the existence of an assortment of complex chemical substances of diverse compositions which occur as secondary metabolites. The most significant of these bioactive constituents of plants are alkaloids, glycosides, tannins, proteins, phenolic compounds and flavanoids [Cragg et al., 2001, Prince et al., 2011].

In the present era of drug development and discovery of newer drug molecules many plant products are evaluated on the basis of their traditional uses. One of the many plants which are being evaluated for their therapeutic efficacies is Achyranthes aspera L.

\section{Distribution and Taxonomy of Achyranthes aspera L:-}

Achyranthes aspera L. (Belongs to family Amaranthaceae) is abundantly found in wastelands. It is distributed throughout India up to an altitude of $3000 \mathrm{ft}$. [Abdul Aziz et al., 2005, Sutar et al., 2011]. It is known as "Prickly chaff flower" shown in (Figure-1). Achyranthes aspera L. (Latjeera) is an erect or procumbent, annual or perennial herb of about 1- 2 meter in height, often with a woody base. Stems angular, ribbed, simple or branched from the base, often with tinged purple colour [Anonymous, 2005], branches terete or absolutely quadrangular, striate, pubescent [Zafar, 2009], leaves thick, $3.8-6.3 \times 22.5-4.5 \mathrm{~cm}$ [Zafar, 2009], ovate - elliptic or obovate -rounded 
[Anonymous, 2005], finely and softly pubescent on both sides, entire, petiolate, petiole $6-20 \mathrm{~mm}$ long [Zafar, 2009], flowers greenish white, numerous in axillary or terminal spikes up to $75 \mathrm{~cm}$ long, seeds subcylindric, truncate at the apex, rounded at the base, reddish brown (Plate:1).

\section{Therapeutic uses of Achyranthes aspera L:-}

Ayurvedic and Yunani practitioners use different parts of the plant to treat leprosy, asthma, fistula, piles, arthritis, wound, insect and snake bite, renal and cardiac dropsy, kidney stone, diabetes, dermatological disorders, gynecological disorders, gonorrhea, malaria, pneumonia, fever, cough, pyorrhea, dysentery, rabies, hysteria, toothache etc [Dey, 2011].

\section{Traditional uses among various tribes:-}

Among the various tribes (Tharu, Buxa, Botiya and Raji/ Vanrawat) found in the study region, the plant is a popular folk remedy in traditional system of medicine. Traditionally, the plant is used in asthma and cough. It is pungent, antiphlegmatic, antiperiodic, diuretic, purgative and laxative, useful in edema, dropsy and piles, boils and eruptions of skin etc. Crushed plant is boiled in water and is used in pneumonia. Infusion of the root is a mild astringent in bowel complaints. The flowering spikes or seeds, ground and made into a paste with water, are used as external application for bites of poisonous snakes and reptiles, used in night blindness and cutaneous diseases [Nadkarni, 2009]. For snake bites the ground root is given with water until the patient vomits and regains consciousness.

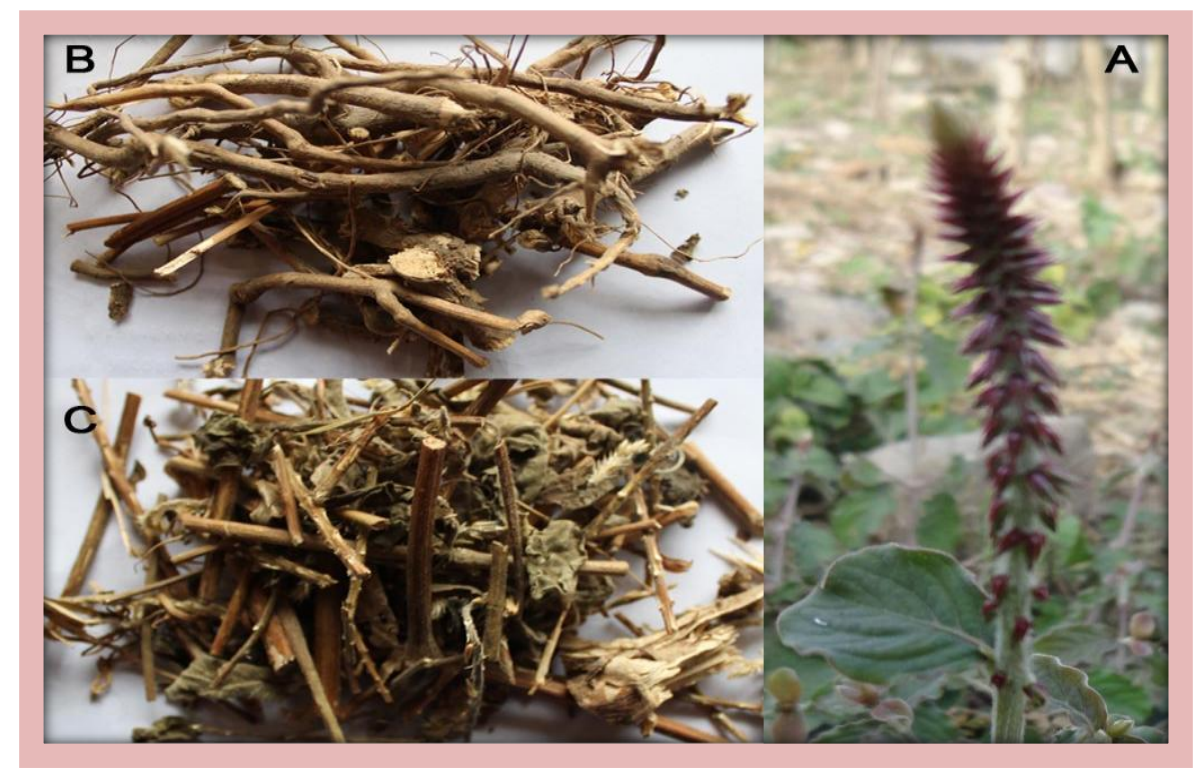

Plate 1:- Achyranthes aspera L.: (A) Live plant (B) Root (C) Leaves and Stem

\section{Study area:}

The present study area, Kumaun (tribal pockets), lies between the altitudes $28^{\circ} 44^{\prime} \mathrm{N}$ and $30^{\circ} 49^{\prime}$ and longitudes $78^{\circ}$ $45^{\prime}$ and $81^{\circ} 1^{\prime}$ E. Kumaun, at its eastern boarder separates with Nepal by Kali river, high transverse mountain spurs separate it from the Chamoli and Pauri districts of Garhwal, a natural water separates from Tibet and the southern limit of the Tarai belt demarcates it's southern boundary. The region constitutes six districts i.e. Almora, Bageshwar, Champawat, Nainital, Pithoragarh and Udham Singh Nagar.

The study is conducted specially in areas abundant with tribal inhabitation viz. Sitarganj, Khatima, Tanakpur, Rudrapur, Gadarpur and Dineshpur for the documentation of Tharu and Buxa local health traditions and Munsyari, Kapkot, Dharamgarh, Bageshwar, Askot and Champawat for Bhotiya and Raji/ Vanrawat local health traditions (Figure:2). 

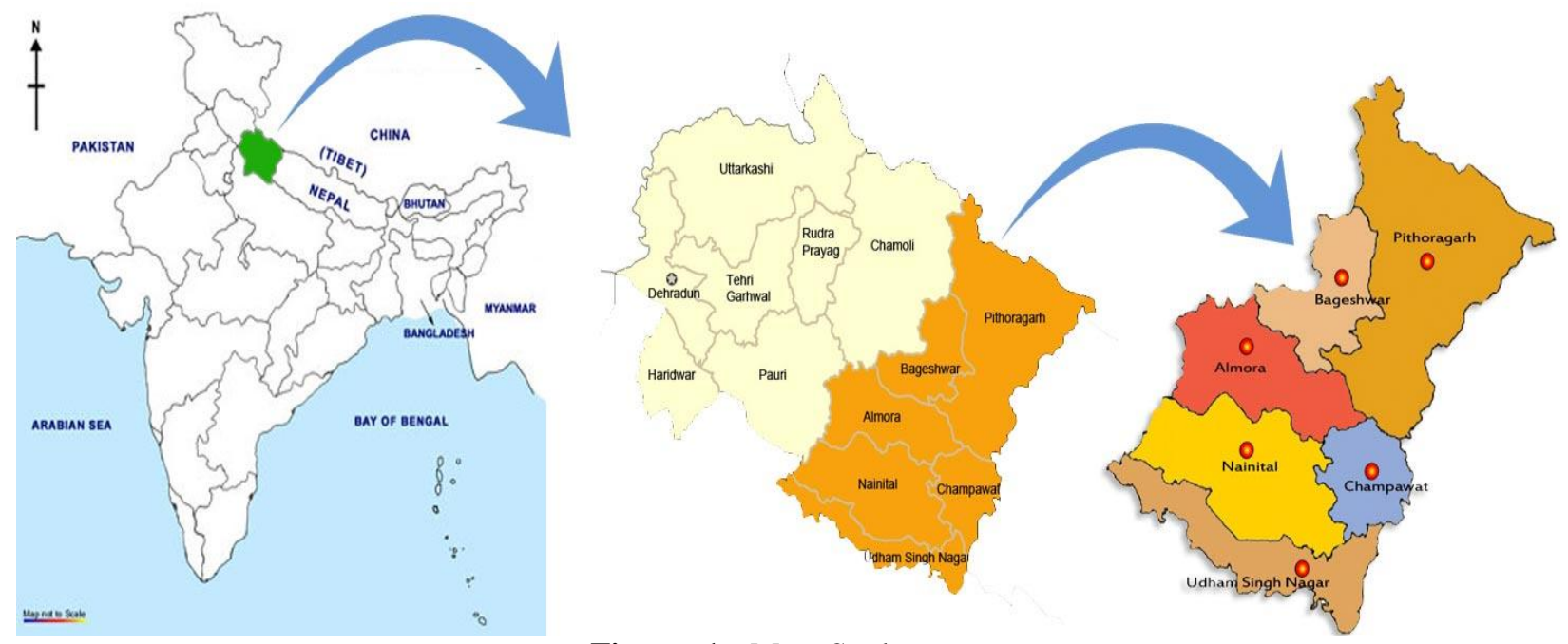

Figure: 1:- Map: Study area.

\section{Material and Methods:-}

In order to gain an understanding of traditional healers and their practice, personnel interview and bilateral discussion were carried out in the premises of healers/informers to duly fill the LHT format. The interview itself covers few main topics: the type of people who are treated (i.e. patient or client groups), the process of healing, the healer's training and practice, his or her role in health promotion and education, and his or her relationship to practitioners of Western approaches to health care.

After gathering the data on the folk uses of Achyranthes aspera L., in the first step, data on was filled in the LHT format given by AYUSH. At the second step, folk uses were validated with the help of codified ayurvedic texts i.e. Ayurvedic Pharmacopeia of India (API), Ayurvedic Formulary of India (AFI), Ayurveda principles, Dravyaguna Vijana by P.V.Sharma, Handbook of Domestic Remedies, Tribal Folk Remedies published by CCRAS (documented but not yet verified) Other than the above references/Ayurveda line etc.

\section{Results:-}

Achyranthes aspera L. is one of the most important plants used by the tribes to cure numerous diseases viz. jaundice, boils, dermatitis, back sprain etc. with different formulations.

From the Buxa tribe, six formulations were documented to cure jaundice, back sprain, cut and wounds, dermatitis, chronic ulcer and earache with different formulations using roots, stem nodes, leaves. One formulation, to cure earache is mentioned in codified Ayurvedic texts. From Tharu tribe, five formulations were documented to cure boils, headache, jaundice, snake bite, piles/internal hemorrhoids. Two formulations, one for snake bite and another for piles/internal hemorrhoids is already mentioned in the codified Ayurvedic texts. While among the Raji/ Vanrawats, two folk uses were documented to cure allergic dermatitis and bone fracture using leaves and roots for different formulation. Formulation used to cure allergic dermatitis is also mentioned in codified Ayurvedic texts (Table: 1.1, 1.2, and 1.3). No folk use was recorded from the Bhotiya tribe. In the 13 folklores, for different diseases $(56 \%)$ leaves, $(31 \%)$ roots and (13\%) stem were used with different formulations (Figure: 2 ). 


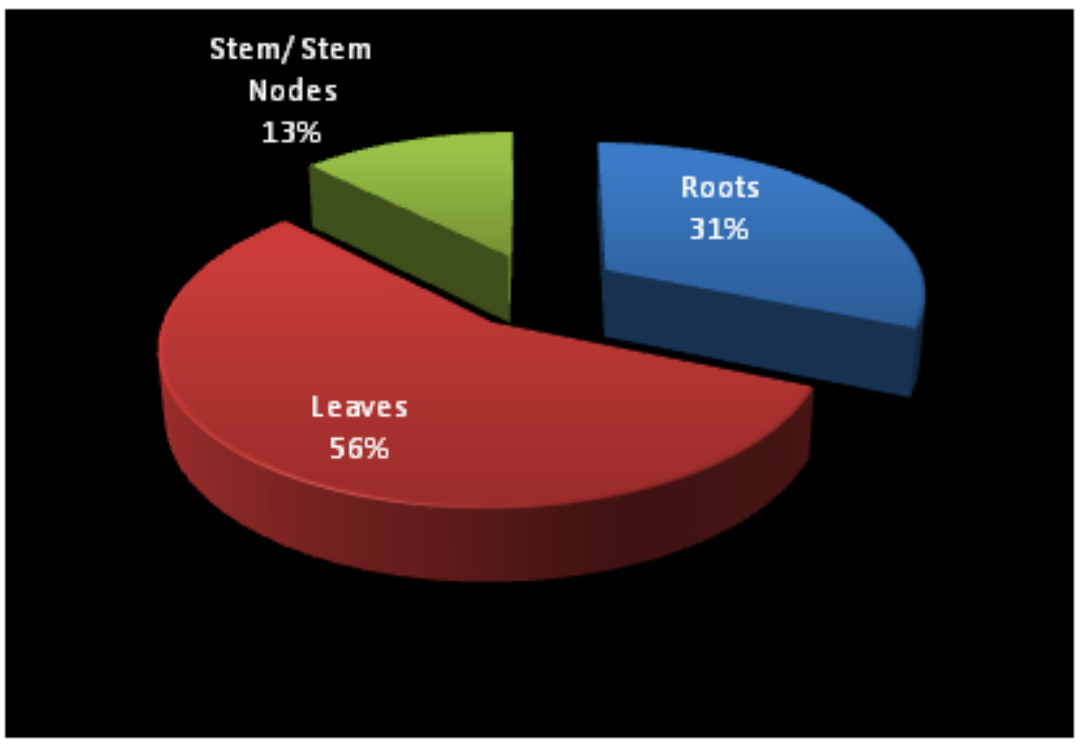

Figure 2:- 43: $\%$ of plant parts used in various formulations.

Table 7:- Achyranthes aspera L.: uses among Buxa tribe with validation.

Achyranthes aspera L: uses among Buxa tribe:-

\begin{tabular}{|c|c|c|c|}
\hline \multicolumn{4}{|c|}{$\begin{array}{c}\text { Achyranthes aspera L.: Amranthaceae } \\
\text { Local Name: Latjeera }\end{array}$} \\
\hline Part used & $\begin{array}{l}\text { Name of Disease } \\
\text { in which used }\end{array}$ & Ethno-medicinal use & $\begin{array}{c}\text { Written in } \\
\text { codified texts } \\
\text { Yes/No }\end{array}$ \\
\hline Roots & Jaundice & $\begin{array}{l}\text { Roots are coarsely grounded and soaked in water, } \\
\text { mashed and filtered. 5-10 ml. filtrate with 'Bans- } \\
\text { Mishri' is given orally to the patient suffering from } \\
\text { Jaundice. }\end{array}$ & NO \\
\hline Stem Nodes & $\begin{array}{l}\text { Back Sprain (Low } \\
\text { back) }\end{array}$ & $\begin{array}{l}\text { Nodes of the stem are fastening with the help of thread } \\
\text { around the low back. }\end{array}$ & NO \\
\hline Leaves & Cuts and Wounds & $\begin{array}{l}\text { Q.S. (quantum sufficit) leaves paste, fried in cow's } \\
\text { ghee, is applied two times daily to cure wounds. }\end{array}$ & NO \\
\hline Leaves & Dermatitis & $\begin{array}{l}\text { Fresh leaves are grounded finely into paste and fried in } \\
\text { mustard oil, made in to jelly form. Q.S. (quantum } \\
\text { sufficit) paste to be applied two times in a day to cure } \\
\text { dermatitis. }\end{array}$ & NO \\
\hline Leaves & Chronic ulcer & $\begin{array}{l}\text { Q.S (quantum sufficit) fresh leaves paste mixed in } \\
\text { cow's ghee, is fastening over wound with help of } \\
\text { bandage. Duration of change is two days to cure } \\
\text { chronic ulcer. }\end{array}$ & NO \\
\hline Leaves/ Roots & Earache & $\begin{array}{l}\text { To cure earache, Q.S. (quantum sufficit) leaves/ root } \\
\text { juice (10-20 mg) instilled in opposite ear of the affected } \\
\text { side. (1-2 Drops B.D. (bis in die). }\end{array}$ & $\begin{array}{c}\text { YES (Ref.: } \\
\text { Anonymous, } \\
\text { 1999: An } \\
\text { Appraisal of } \\
\text { Tribal folk } \\
\text { medicines, } \\
\text { CCRAS, pp. } \\
\text { 125. }\end{array}$ \\
\hline
\end{tabular}


Table 8:- Achyranthes aspera L.: uses among Tharu tribe with validation.

Achyranthes aspera L.: uses among Tharu tribe:

\begin{tabular}{|c|c|c|c|}
\hline \multicolumn{4}{|c|}{$\begin{array}{l}\text { Achyranthes aspera L.: Amranthaceae } \\
\text { Local Name: Chirchita, Apamarga }\end{array}$} \\
\hline Part used & $\begin{array}{l}\text { Name of Disease } \\
\text { in which used }\end{array}$ & Ethno-medicinal use & $\begin{array}{c}\text { Written in codified texts } \\
\text { Yes/No }\end{array}$ \\
\hline Leaves & Boils & $\begin{array}{c}\text { Fresh leaves are heated over low flame and } \\
\text { applied locally over the boils. }\end{array}$ & NO \\
\hline Leaves & Headache & $\begin{array}{l}\text { Leaves juice is applied over forehead to relieve } \\
\text { pain. }\end{array}$ & NO \\
\hline Root and Stem & Jaundice & $\begin{array}{l}\text { (i) } 1 \text { gram root paste with pepper is given orally } \\
\text { one time in a day o cure jaundice. } \\
\text { (ii) Fresh stem is cut in to size of distal phalanx } \\
\text { of index finger. Stem piece is tide around head } \\
\text { with the help of a thread as garland to cure } \\
\text { jaundice. }\end{array}$ & NO \\
\hline Leaves & Snake Bite & $\begin{array}{l}5 \mathrm{gm} \text { leaves paste is given to the patient } \\
\text { suffering from snake poison. }\end{array}$ & $\begin{array}{c}\text { YES (Ref.: Sharma, } \\
\text { P.V. 1979. Dravyaguna- } \\
\text { Vigyaan, Shree Sharma } \\
\text { Ayurveda } \\
\text { Mandir,Varanasi, } \\
\text { Vol.II, pp.543. } \\
\text { Anonymous. Ayurvedic } \\
\text { Pharmecopoiea of India, } \\
\text { Vol.II, pp.7.) }\end{array}$ \\
\hline $\begin{array}{l}\text { Roots and } \\
\text { Leaves }\end{array}$ & $\begin{array}{l}\text { Piles/ Internal } \\
\text { Hemorrhoids }\end{array}$ & $\begin{array}{c}30 \mathrm{gm} \text { powder of roots and leaves of } \\
\text { Achyranthes aspera L. is mixed with } 10 \mathrm{gm} \\
\text { pepper powder. } 10 \mathrm{gm} \text { powder is taken orally } \\
\text { thrice daily to cure Piles/ Internal } \\
\text { hemorrhoids. }\end{array}$ & $\begin{array}{l}\text { YES (Ref.: Sharma, P.V. } \\
\text { 1979. Dravyaguna- } \\
\text { Vigyaan, Shree Sharma } \\
\text { Ayurveda } \\
\text { Mandir,Varanasi, Vol.II, } \\
\text { pp.309) }\end{array}$ \\
\hline
\end{tabular}

Table 9:- Achyranthes aspera L.: uses among Raji/ Vanrawat tribe with validation.

Achyranthes aspera L.: uses among Raji/ Vanrawat tribe:

\begin{tabular}{|c|c|c|c|}
\hline \multicolumn{4}{|c|}{$\begin{array}{l}\text { Achyranthes aspera L.: Amranthaceae } \\
\text { Local Name: Chirchita, Apamarga }\end{array}$} \\
\hline Part used & $\begin{array}{l}\text { Name of Disease } \\
\text { in which used }\end{array}$ & Ethno-medicinal use & $\begin{array}{l}\text { Written in codified } \\
\text { texts Yes/No }\end{array}$ \\
\hline Leaves & $\begin{array}{c}\text { Allergic } \\
\text { Dermatitis }\end{array}$ & $\begin{array}{r}\text { Leaves paste is applied over affected part to } \\
\text { cure allergic } \\
\text { dermatitis. }\end{array}$ & $\begin{array}{c}\text { YES ( Ref.: Sharma, } \\
\text { P.V. and Sharma, } \\
\text { Guruprasad, 1979. } \\
\text { Keyadev Nighantu, } \\
\text { Chaukhamba } \\
\text { Orientalia, Varanasi) }\end{array}$ \\
\hline Roots & Bone fracture & $\begin{array}{c}\text { Roots are grounded with gur (Jiggery) and } \\
\text { tablets are formed. } 5-8 \text { gm tablet is given with } \\
\text { milk two times in a day to cure inflammation } \\
\text { due to bone fracture. }\end{array}$ & NO \\
\hline
\end{tabular}




\section{Conclusion and Discussion:-}

The herbals occupied a distinct place in the life right from the primitive period till date and provided information on the use of plants or plant products and products as medicine. The use of medicinal plants in the management of various illnesses is due to their phyto-chemical constituents and dates back antiquity [Chahlia, 2009]. Despite the development of rural health services, villagers still use medicinal herbs to a large extant for treatment of common ailment like cough, cold and fever, headache and body ache, constipation, dysentery, cuts and burns, boils, jaundice, ulcer, skin and respiratory diseases etc.

From this study, it is clear that Achyranthes aspera L. is an important source of many therapeutically and pharmacologically active constituents. The plant has been widely studied for its pharmacological activities and finds its position as a versatile plant having a wide spectrum of medicinal activities. Presence of wide range of phytochemicals indicates its promise in herbal medicine.

The plant was found to be very useful in the treatment of jaundice in ethno-medicine. Widespread ethnic use of the plant against snakebite makes it a potent anti-venomous plant. The plant is an ingradient of Ksharsutraan Ayurvedic preparation used in the treatment of fistulain- ano. Antitumour and cytotoxic potential are the exciting aspects of the plant. The plant is a potent immune-stimulant too (Dey, 2011). Several investigators have reported the plant as a valuable antibacterial, antifungal, larvicidal and active against other plant pathogens.

Thus, the study clarifies Achyranthes aspera L. as the most promises drug among the all plant species used in local health traditions. For further researches on this species will result in the formation of new data on the medical field. The distribution of knowledge and awareness among local people, regarding the importance of this plant will also help to enhance the plant research.

\section{References:-}

1. Abdul Aziz Md. Mizanur Rahman Md, Anjon KM, Tanvir M, Azizur Rahman Md, Abdul Quader Md. (2005). 3-Acetoxy-6-benzoyloxyapangamide from Achyranthes aspera", Dhaka University Journal Pharmaceutical Sciences; 4(2):113-116.

2. Anonymous (2005). The Wealth of India - Raw Materials, Council of Scientific \& Industrial Research, New Delhi, 55-57.

3. Chahlia, N. (2009). Effect of Capparis decidua hypolipidemic activity in rats. Journal of medicinal plants research, 3(6), 481-484.

4. Cragg, G.M., Newman, D.J. (2001). Medicinals for the millennia, Annny Acad Sci, 953:3-25.

5. Dey, A. (2011). Achyranthes aspera L.: Phytochemical and Pharmacological aspects, International journal of pharmaceutical sciences review and research, volume 9, pp- 72-82.

6. Mukherjee, P.K. (2008). Quality control of herbal drugs. Business Horizon Pharmaceutical Publishers, Vol. 13.

7. Nadkarni, K.M. (2009). Indian Materia Medica. Bombay Popular Prakashan, Vol.I, 21.

8. Prince, L., Prabhakaran, P. (2011). Antifungal activity of medicinal plants against plant pathogenic fungus collector Trichum falcatum, Asian Journal Plant Science Research, Vol. 1(1):84-87.

9. Sutar, N., Garai, R., Sharma U.S., Goyal, P., Yadav, G. (2011) "Pharmacognostic Studies of the Achyranthes aspera Leaves", Pharmacie Globale International Journal of comprehensive pharmacy, 5(10):15-20.

10. Zafar, R. (2009). Medicinal Plants of India. CBS publishers \& distributors, 1-15. 